\title{
In search of the optimum Raman/IR signatures of potential ingredients used in San/Bushman rock art paint
}

\author{
Linda C. Prinsloo ${ }^{\mathrm{a}}$, Aurélie Tournié ${ }^{\mathrm{a}}$, Philippe Colomban ${ }^{\mathrm{b}}$, Céline Paris ${ }^{\mathrm{b}}$ and Stephen \\ T. Bassett ${ }^{\mathrm{a}, \mathrm{c}}$. \\ ${ }^{a}$ University of Pretoria, Physics Department, Lynnwood Rd, Hatfield, Pretoria, 0002 (South Africa). \\ ${ }^{b}$ Laboratoire de Dynamique, Interaction et Réactivité (LADIR), UMR7075 CNRS, Université Pierre- \\ et-Marie-Curie/Paris 6, c49, 4 Place Jussieu, 75005 Paris (France). \\ ${ }^{c}$ Sewefontein Studio and Gallery, Sterkstroom, P.O. Box 2211, Komani 5322, Eastern Cape (South \\ Africa).
}

\begin{abstract}
Vibrational spectroscopy (Raman and FTIR) has played an important role in identifying pigments, substrata and deterioration products in rock art studies worldwide: in the laboratory and on-site. However, the detection of organic binders and carrying agents has so far been scarce and the quality of many spectra recorded on-site inadequate. In this study, possible pigments (charcoal, ochre, raptor faeces, thermally treated ostrich egg shell, etc.), binders (fat, egg, blood) and carrying agents (saliva, gall, egg, water) were selected based on artistic considerations and analysed with FTIR and Raman (514.6 and $785 \mathrm{~nm}$ excitation, both available in mobile instruments) spectroscopy in order to determine usable marker bands for each ingredient. The resultant marker bands were then used to analyse five San replica paints. It was found that FTIR spectroscopy is very efficient to identify organic compounds as there is no fluorescence but the broadness of the bands inhibits the exact assignment of many ingredients. A high fluorescence background experienced for many natural products prevented the recording of Raman spectra for all ingredients, in many instances though the sharp peaks usually associated with Raman spectra make identification easier than with FTIR spectroscopy. Most of the ingredients in the paints could be identified, but it is clear that better results are obtained when more that one technique is used.
\end{abstract}

Keywords: San/Bushman rock art, FTIR, Raman, ingredients, replica paints 


\section{Introduction}

Rock art has been a topic of study in many parts of the world over a long period of time and vibrational spectroscopy (Raman and FTIR) has played an important role in identifying pigments, substrata and deterioration products (Bonneau et al., 2012; Edwards et al., 1998, 1999, 2000; Hernanz et al., 2006, 2008, 2010, 2012; Goodall et al., 2009; Lufromento et al., 2012; Prinsloo et al., 2008; Smith et al., 1999; Zoppi et al., 2002). The advent of portable instruments has added the extra bonus of performing analyses on-site, making it possible to study paintings of choice in their original setting, with a non-destructive and non-invasive technique (Lahlil et al., 2012; Olivares et al., 2012; Ravindran et al., 2013; Tournié et al., 2010). This was a great breakthrough as previously, only paint on shards that have detached from the rock face or samples collected from the paintings, a practice to be avoided, could be studied. However, although inorganic pigments/deterioration products such as ochre, manganese oxide, calcite, sulphate etc. have been detected through their Raman spectra in many rock art studies (in the laboratory and on-site), the detection of organic binders and carrying agents have so far been scarce and the quality of many spectra recorded on-site not very good. The improvement of detection techniques is therefore of the utmost importance for all scientists interested in studying rock art. The greatest interest is for on-site analyses and as the planning and execution of such expeditions are expensive with limited time, there is a need to determine beforehand the most efficient methods to analyse the art and to predict what to expect in the paint.

The paint used by Bushman/San cave artists consists of both inorganic and organic components such as pigments (charcoal, manganese oxide, haematite, goethite, clay ...), carrying agents (saliva, gall, egg, plant sap, water) and binding agents (fat, egg, blood, plant resin) (Bassett, 2001; Johnson, 1957; Rudner, 1983). According to ethnographic records and oral traditions the ingredients were selected not only for their colour and adhesion properties, but also for symbolic reasons. Eland blood for example, was used to add strong spiritual potency to the paintings (LewisWilliams, 1985; Lewis-Williams and Dowson, 1990).

In this preliminary study the tools and ingredients available to San/Bushman cave artists were identified and possible paint mixtures formulated. The paint samples were then tested for viability by replicating San rock paintings (Fig. 1), using only ingredients and implements (such as brushes) made from material collected in the 


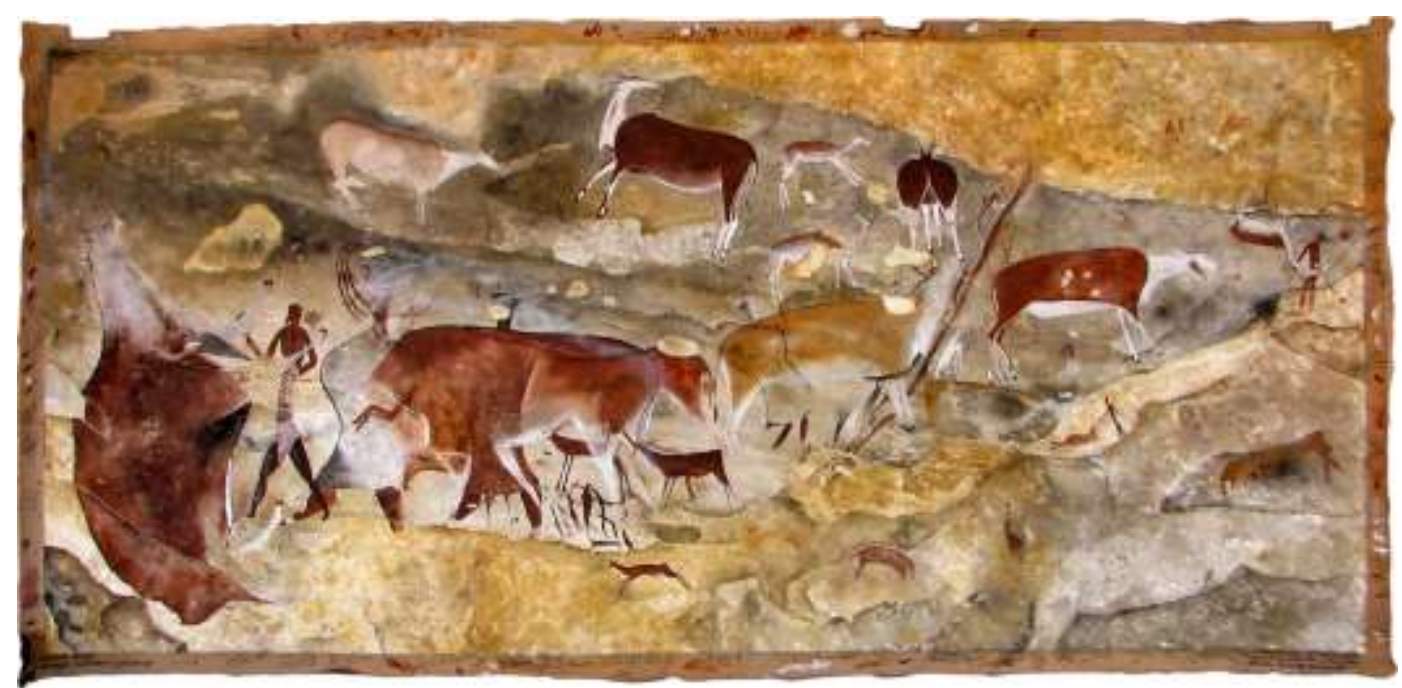

Figure 1: Replica painting $(2 \times 1 \mathrm{~m})$ of a scene on the roof of Christmas shelter, a rock art site in the uKhahlamba Drakensberg National Park, South Africa. Currently it hangs in the Rock Art Research Institute at the University of the Witwatersrand, Johannesburg, South Africa. More details at the following websites. http://stephentownleybassett.co.za/HeritageWork.html http://www.wits.ac.za/academic/science/14232/news.html\#

South African veld (Bassett, 2001). In other words the paints were tested from an artistic perspective, which has not been done before, although quite a few scientists have experimented with paints and many suggestions have been made about the ingredients used by San artists (Rudner 1983, Johnson 1957). Not all the ingredients previously suggested make viable paints though. Combinations also do not always work e.g. water or plant sap will act as a good carrier when added to an egg or blood formulation, but will be ineffective with fat-based formulations. Flow properties, mixing ability, colour density, durability and compatibility with the surface to which they are applied are important from an artist's view and the paints were tested in this regard (Fig. 2). Some of these raw ingredients that may have been used by San artists were selected and infrared and Raman spectra $(514.6 \mathrm{~nm}$ and $785 \mathrm{~nm}$ excitation representative of the lines used in (ultra) mobile Raman instruments were recorded. The aim of this study was to identify marker bands for each ingredient. Spectra were then recorded for one red, one yellow, two white and one black paint-mixture and the marker bands used to identify the raw ingredients in the paints. This made it possible to select the most efficient method to detect a specific ingredient in paint. 

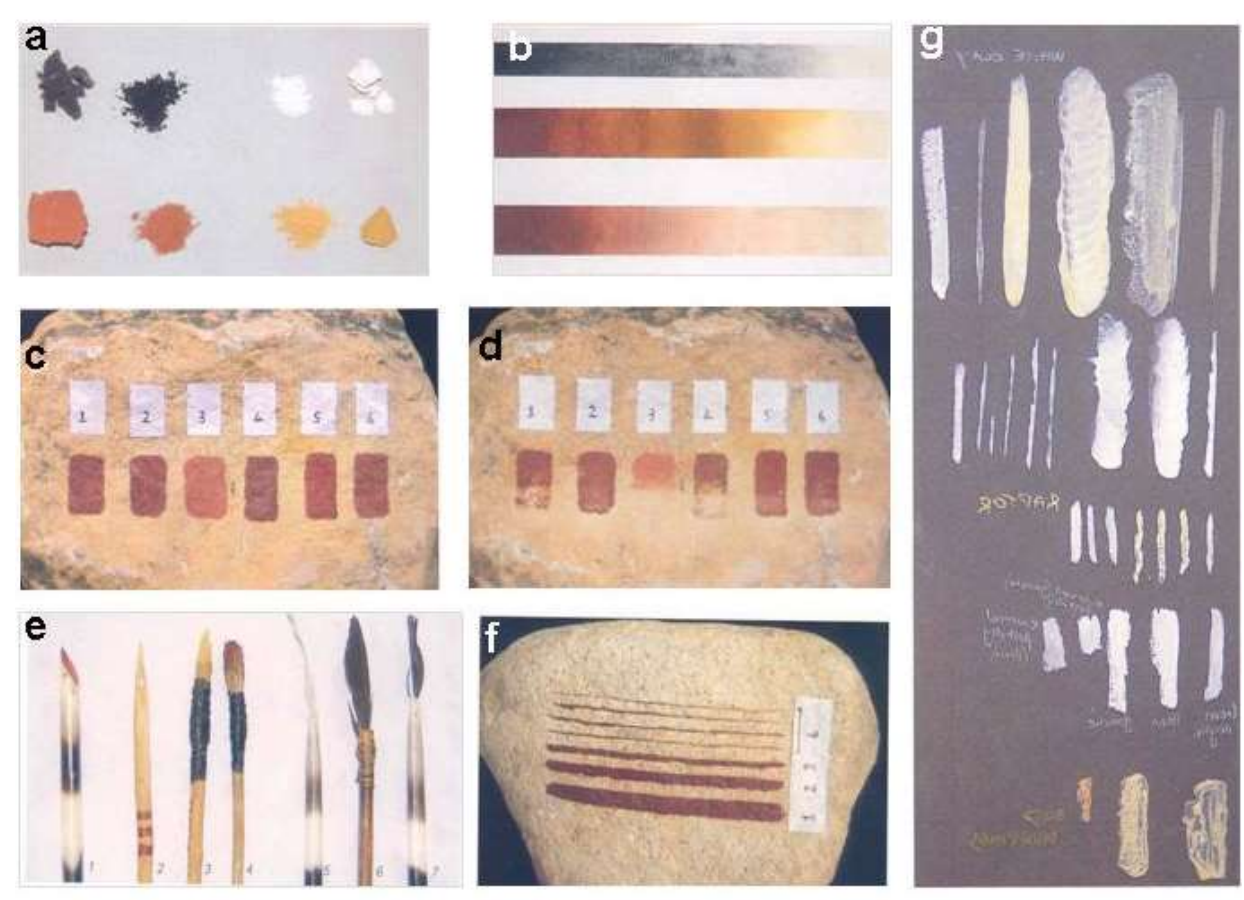

Figure 2: a) natural pigments and b) colour gradations possible using only four pigments. Testing different mixtures for colour fastness c) 1) ochre, fat, blood 2) ochre, fat, egg 3) ochre, water 4) ochre, egg, blood 5) ochre, fat, gall 6) ochre, fat, gall, blood d) the bottom part of the paint samples were abraded with water and sand e) Experimenting with natural brushes. The thin lines f) were drawn with the edge of a feather brush, $g$ ) Comparing the brilliance of white paints.

Details about the preparation of the paints is given in L. Ronat, Spotlight on San Paintings, CNRS-Images film (32 min),

http://videotheque.cnrs.fr/index.php?urlaction=doc\&id_doc=2223 (accessed

November 2012)

http://www.youtube.com/watch?v=v_7RvWeQxZM (accessed November 2012)

\section{Materials and Methods}

\subsection{Raw materials: pigments}

The symbolic and practical use of ochre in Africa since pre-historic times is well established (Rifkin, 2012, Wadley 2005, Wadley et.al. 2004)) and its use as pigment is confirmed by the recent discovery of a 100000 -year-old ochre-processing workshop at Blombos Cave, South Africa (Henshilwood et al., 2008). Ochre, bone, charcoal, grindstones and hammerstones form part of this production toolkit and a liquefied ochre mixture was found stored in abalone shells. Therefore, the use of ochre as pigment was common practice and today is still used to produce red and yellow earth colours. Ochres have been studied extensively using Raman spectroscopy and pigments from different sources give slightly different spectra, depending on the composition of local clays (Froment et al., 2008, Hernanz et. al. 2008, Gialanella et. al. 2011). The ochres used in this study (yellow and red) are from 
the Wonderwerk cave in the Northern Cape, an archaeological site with an occupation history since the Middle Pleistocene Age (Avery, 2007). Ethnographic records and oral tradition suggest that San artists preferably used specularite, a crystalline form of haematite that is steel-grey/iron black in colour with a metallic sparkle, for their red paint. The specularite used in this study originates from Blinkklipkop, a prehistoric mine where mining began some time before $800 \mathrm{AD}$ by the San and Khoi then later Tswana communities as it was also highly prizes as cosmetic (Thackeray et al., 1983). Black pigments obtained from natural sources that has previously been detected in prehistoric rock art is either charcoal or manganese oxides, but in San rock art so far only carbonaceous material has been detected. White clay is relatively scarce in South Africa and other sources for white pigment were investigated. Raptor faeces are brilliantly white and soft to work with and make an excellent paint. Experimentation showed that calcined ostrich egg shell powder (96.5\% calcite, $2.7 \%$ organics) makes an excellent paint and after combustion consists of nearly pure calcium oxide, which easily converts to calcium hydroxide and after time to calcium carbonate (Bezuidenhout et al., 2010). Bone white is another possibility for white pigments or lightener and has been in use all over the world since ancient times. Hyena dung is pure white (Fig. 3) and another source of white pigment and is found all over South Africa as the occurrence of hyenas are widespread.

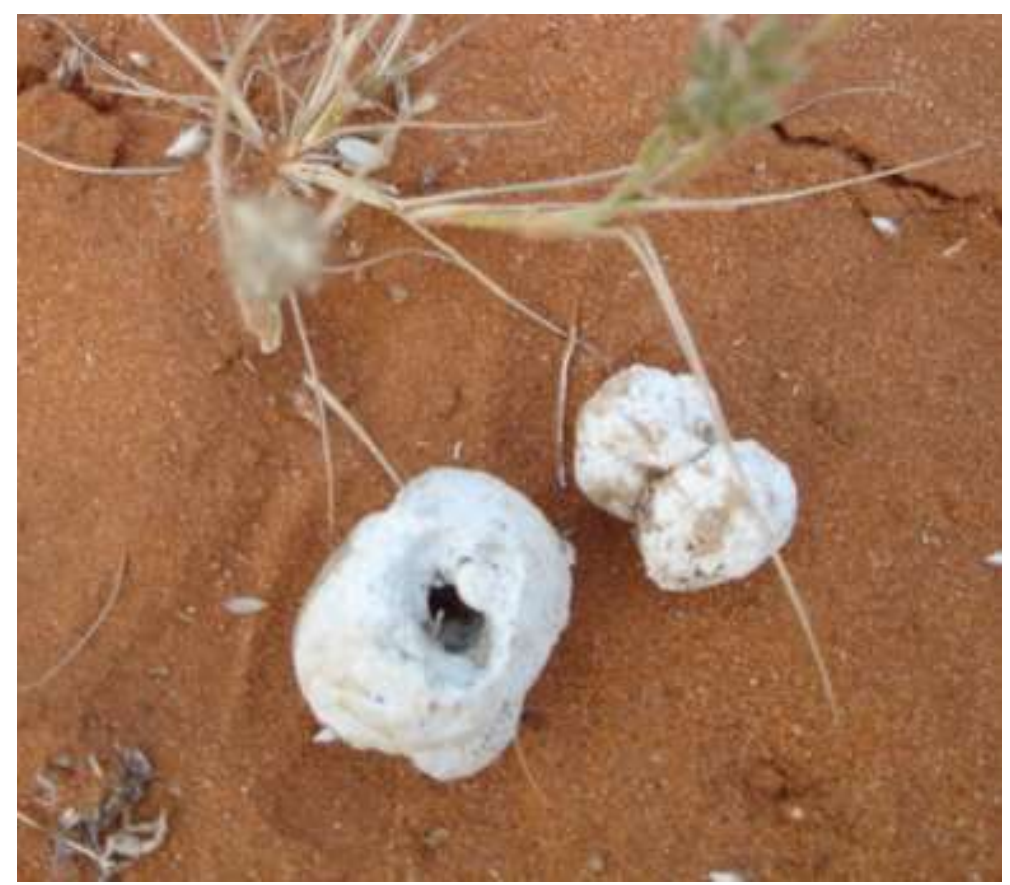

Figure 3: Hyena dung (Kgalagadi Transfrontier park, Botswana) 


\subsection{Raw materials: Binding and carrying agents}

The paints analysed in this study were formulated after extensive experimentation with natural materials. In Fig. 2 some of the experiments, where different aspects of various paint mixtures were tested, are illustrated. Fig. 2a\&b demonstrates the different colour gradations that are possible using only four natural pigments. In Fig. 2c different paint mixtures were tested for colour fastness by applying the mixtures namely (1) ochre, fat, blood; 2) ochre, fat, egg; 3) ochre, water; 4) ochre, egg, blood; 5) ochre, fat, gall and 6) ochre, fat, gall, blood to a sandstone rock surface. The bottom half of each paint rectangle was then abraded with water and sand and in Fig.2d it can clearly be seen that animal fat and a mixture of fat and egg are the best binding agents (rectangles 2, 5 and 6). Various brushes made from natural material were tested for the ability to draw the fine lines typical of San rock art using the paint mixtures (Fig. 2e\&f) and the brilliance of the white paint mixtures were tested against commercial paints (Fig. 2g). Plant sap from certain plants can also perform a binding function and this aspect should form part of future studies. (Bassett 2002).

\subsection{Paint samples}

Five different paint samples prepared ten years ago and used to paint life size replica paintings (Fig. 1) were selected for analyses. The different ingredients used to make the paints are listed in Table 1 and the preparation method of the paints is documented in a CNRS images film "Spotlight on San paintings" (Ronat, 2012).

\subsection{Experimental detail}

Raman spectra were recorded with different instruments. The Raman spectra excited with the 514.6 line of a Coherent Innova ${ }^{\circledR} 70 \mathrm{C}$ Series Ion Laser System were recorded using a T64000 micro-Raman spectrometer from HORIBA Scientific, Jobin Yvon Technology (Villeneuve d'Ascq, France). The laser power $(0.1-10 \mathrm{~mW}$ ) at sample) and acquisition time (50-200S) varied according to the degree of fluorescence displayed by the samples. A Senterra Raman instrument from Bruker Optics was used to record spectra with $785 \mathrm{~nm}$ excitation. This instrument has a resolution lower than the first instrument but rather similar to the best portable Raman spectrometers (Colomban, 2012). The 100x or 50x objectives of an Olympus microscope was used 
Table 1: List of the raw materials and paint mixtures studied

\begin{tabular}{|c|c|c|c|c|c|c|c|c|}
\hline \multirow{2}{*}{$\begin{array}{c}\text { Paint } \\
\text { Sample }\end{array}$} & \multirow{2}{*}{ Colour } & \multirow{2}{*}{ Pigment } & \multicolumn{3}{|c|}{ Carrying agent } & \multicolumn{2}{|c|}{ Binding agent } & \multirow{2}{*}{\begin{tabular}{|c|}
$\begin{array}{l}\text { Carrying and } \\
\text { binding }\end{array}$ \\
$E g g$
\end{tabular}} \\
\hline & & & Saliva & Gall & Water & Fat & Blood & \\
\hline 1 & Dark red & Specularite & & & & $\mathrm{x}$ & & $\mathrm{x}$ \\
\hline 2 & Yellow & ochre & $\mathrm{x}$ & & & & & $\mathrm{X}$ \\
\hline 3 & White & raptor faeces & $\mathrm{x}$ & & $\mathrm{x}$ & & & white \\
\hline 4 & White & bone white & & & & & & $\mathrm{X}$ \\
\hline 5 & black & charcoal & $\mathrm{X}$ & $\mathrm{x}$ & & & $\mathrm{x}$ & $\mathrm{X}$ \\
\hline
\end{tabular}

\begin{tabular}{|l|l|l|l|l|}
\hline Ingredients & Pigment & Carrying agent & Binding agent & $\begin{array}{l}\text { Carrying and } \\
\text { binding }\end{array}$ \\
\hline Raptor faeces & white & & & \\
\hline Hyena dung & white & & & \\
\hline Bone white & white & & \\
\hline Cobra venom & \multicolumn{2}{|c|}{ Adding symbolic power to painting } \\
\hline Specularite & red & \multicolumn{3}{|l|}{} \\
\hline Red ochre & red & & & \\
\hline Yellow ochre & yellow & & & \\
\hline White clay & white & $\mathrm{x}$ & $\mathrm{x}$ & $\mathrm{x}$ \\
\hline Egg & \multicolumn{5}{|l|}{} \\
\hline Fat (cow) & & & $\mathrm{x}$ & $\mathrm{x}$ \\
\hline Marrow fat (cow) & & $\mathrm{x}$ & $\mathrm{x}$ & $\mathrm{x}$ \\
\hline Blood (human) & & $\mathrm{x}$ & & \\
\hline Gall (blesbok) & & & & \\
\hline
\end{tabular}

to focus the laser beam on the samples. Objectives optimised for the IR range were used for the $785 \mathrm{~nm}$ excitation.

Infrared spectra were recorded using a diamond ATR cell, which fits in the macro sample compartment of a Vertex 70v (Bruker Optics) spectrometer. The sample compartment was evacuated during acquisitions and the contact area between the sample and the diamond ATR crystal is $2 \mathrm{~mm}$ diameter. Spectra were recorded with 32 acquisitions at $4 \mathrm{~cm}^{-1}$ resolution over a spectral range of $4000-400 \mathrm{~cm}^{-1}$.

GS/MS spectra were recorded using a GC/MS HP 5890 instrument. The analytical procedure used to identify minor quantities of proteins has been described by A. Derieux et al. (2001) and Marinach et al. (2004). The experiment was carried out using gas chromatography/mass spectrometry ions traps after hydrolysis and derivatisation by ethyl chloroformate of the binder. 


\section{Results and discussion}

\subsection{FTIR}

In Figure 4 spectra of possible carrying agents (blesbuck gall, egg, blood) and binding agents (animal fat and egg) are shown. The two top spectra are both of animal fat, but the fat of the uppermost spectrum was liquefied by heating, in order to make it possible to blend into a paint mixture. Prominent bands in all the spectra, except the heated fat, are the amide I ( $\vee \mathrm{C}=\mathrm{O}$ stretching mode) and amide II (bending vibrations from C-N mode) bands typical of proteins (Gallagher website). The presence of these two bands in a spectrum could indicate the presence of a protein, but identifying the origin of the protein would be difficult based on these two bands only. In the spectrum of heated animal fat the amide I and II bands have disappeared (due to the separation of protein and fat upon heating) and the spectrum has characteristic bands at $1740 \mathrm{~cm}^{-}$ ${ }^{1}$ (carbonyl stretch), $1466 \mathrm{~cm}^{-1},\left(\mathrm{CH}_{2}\right.$ and $\mathrm{CH}_{3}$ bending), $1175 \mathrm{~cm}^{-1}$ (C-O stretching) and $722 \mathrm{~cm}^{-1}\left(\mathrm{CH}_{2}\right.$ rocking), which in combination would be good marker bands (Vandenabeele et al., 2000; Baeton, 1998). The spectrum of blesbuck gall has a doublet at 1048 and $1073 \mathrm{~cm}^{-1}$, which could be used as marker bands together with the presence of protein bands (Table 2).

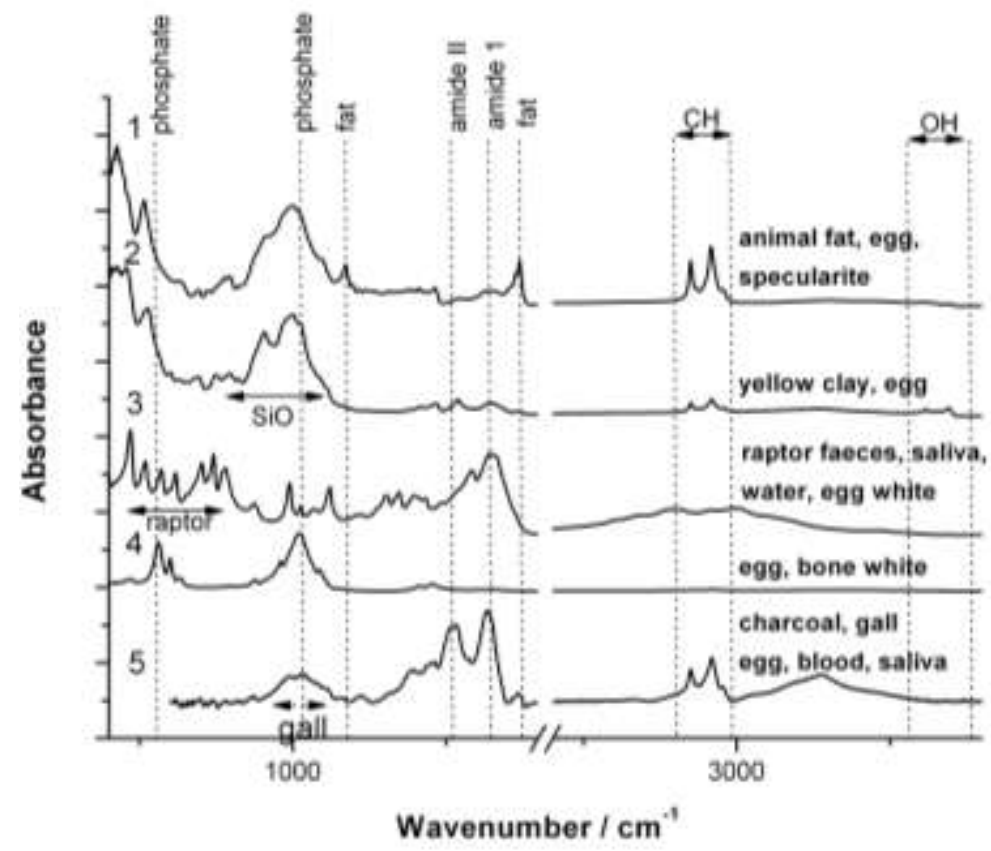

Figure 4: FTIR spectra of five replica paints 
There are small differences between the spectra of human blood and egg white, but it would be difficult to distinguish between them in a natural sample. Egg white consists mainly of proteins such as albumen with less than $1 \%$ carbohydrates. In contrast the egg yolk consists of protein, cholesterol, carbohydrates and fatty acids as seen in the chromatograms presented in Figure S1. The strongest bands in the chromatogram for egg yolk belongs to unsaturated fatty acids (oleic, linoleic and palmitoleic), as well as the saturated fatty acids (palmitic, stearic and myristic). This is reflected in the infrared spectra of egg yolk and white (Figure 5). The egg yolk spectrum has a strong carbonyl band at $1744 \mathrm{~cm}^{-1}$ originating from cholesterol and fatty acids, a distinctive triplet at 1087, 1162 and $1232 \mathrm{~cm}^{-1}$ and the intensity of the $\mathrm{CH}_{2}$ vibrations are much higher than for the egg white, due to the long chain fatty acids (palmitic and oleic acids). It is however most likely that the whole egg would have been used by the Bushmen, except for white paint where it is quite possible that egg white was selected. If both egg and fat are constituents of the paint there might be a problem distinguishing between them.

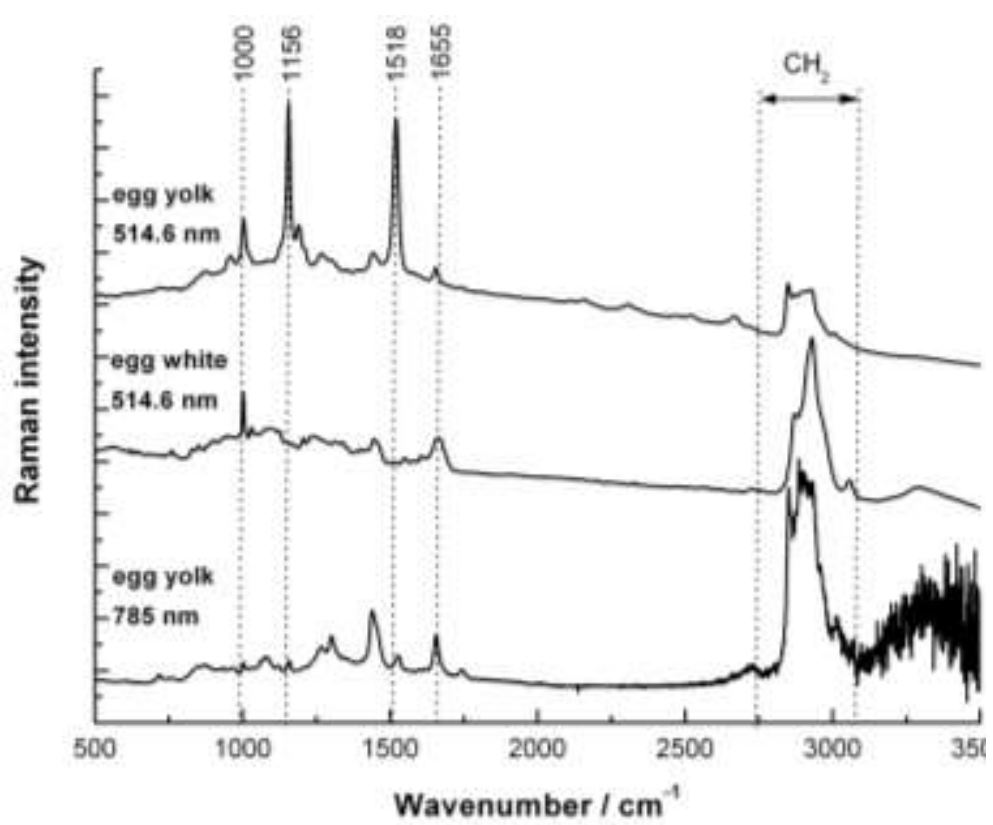

Figure 5: Raman spectra of egg yolk $(514.5$ and $785 \mathrm{~nm})$ and egg white recorded with $514.6 \mathrm{~nm}$ excitation.

Spectra recorded for the pigments (raptor faeces, calcined ostrich egg shell, bone white, hyena dung, specularite, red, yellow and white clay) are presented in Figure 6. Raptor faeces consist mainly of uric acid and the strongest bands occur at $1658(\mathrm{C}=\mathrm{O}$ 
stretch and $\mathrm{H}_{2} \mathrm{O}$ bending) and $1582 \mathrm{~cm}^{-1}\left(\mathrm{NH}_{2}\right.$ asymmetric deformation). In a mixture these two bands might overlap with protein bands (see Fig. 6) and on their own not ideal marker bands for raptor faeces. However three prominent sharp peaks at 777 $\left(\mathrm{CH}_{2}\right.$ rocking), 742 (mixture of $\mathrm{C}-\mathrm{C}$ stretch, N-H out-of-plane bending and C-N stretch of aromatic), $702 \mathrm{~cm}^{-1}$ (libr $\mathrm{H}_{2} \mathrm{O}$ ) are quite characteristic of uric acid and in fact used to identify kidney stones (Wilson et. al. 2010). The appearance of these peaks in combination with the peaks at 1658 and $1582 \mathrm{~cm}^{-1}$ can be used as marker bands for raptor faeces. The spectrum of heated ostrich egg shell displays bands of calcite (1404 and $\left.874 \mathrm{~cm}^{-1}\right)$ as well as calcium hydroxide $\left(3642 \mathrm{~cm}^{-1}\right)$. Ostrich egg shell consists of $96.5 \% \mathrm{Mg}_{0.03} \mathrm{Ca}_{0.97}\left(\mathrm{CO}_{3}\right)$ and $2.7 \%$ organic material. Grinding the ostrich egg shell to produce a powder is a difficult task and the resultant powder has a coarse texture making it impossible to use as a pigment. On the other hand, heating the shells partly combusts the organic material (mostly protein) to carbon, which turns the shells grey to black and after complete combustion only $\mathrm{CaO}$ remains, a fine white powder and an excellent pigment (Bezuidenhout et al., 2010). However, exposure to the atmosphere converts $\mathrm{CaO}$ to $\mathrm{CaOH}$ quite rapidly and then finally the $\mathrm{CaOH}$ reacts with $\mathrm{CO}_{2}$ in the air to form $\mathrm{CaCO}_{3}$. It is therefore to be expected that in rock art paintings $\mathrm{CaCO}_{3}$ will be the phase that is present. The two other white pigments are calcined bovine bone (bone white) and hyena dung. Bone white consists of crystalline phosphate and the FTIR spectrum has two strong sharp bands at 1020 and $562 \mathrm{~cm}^{-1}$. In contrast the spectrum of hyena dung, consisting mostly of digested bones, exhibits peaks in the same region, but broader and slightly shifted to lower wavenumbers, suggesting that the apatite have a low degree of crystallinity. The spectra of the three clay minerals exhibit strong bands between $900-1200 \mathrm{~cm}^{-1}$ originating from various $\mathrm{Si}-\mathrm{O}$ stretch vibrations and have very characteristic peaks of $\mathrm{OH}$ stretch vibrations at 3620 and $3628 \mathrm{~cm}^{-1}$ characteristic of kaolinite (Madejova, 2003) which can be used to identify the presence of clay. However, the FTIR spectra of the three clays (white, yellow and red) from Wonderwerk cave are very similar and it will not be possible to distinguish between them as peaks originating from the clay minerals dominate the spectra and no clear signal of the pigments are detected. The specularite spectrum has a broad band at $\sim 1000 \mathrm{~cm}^{-1}$ and a fairly sharp peak at $512 \mathrm{~cm}^{-1}$, also observed in the three clay minerals. Charcoal has no specific peaks in the infrared and can therefore not be detected with FTIR spectroscopy. 


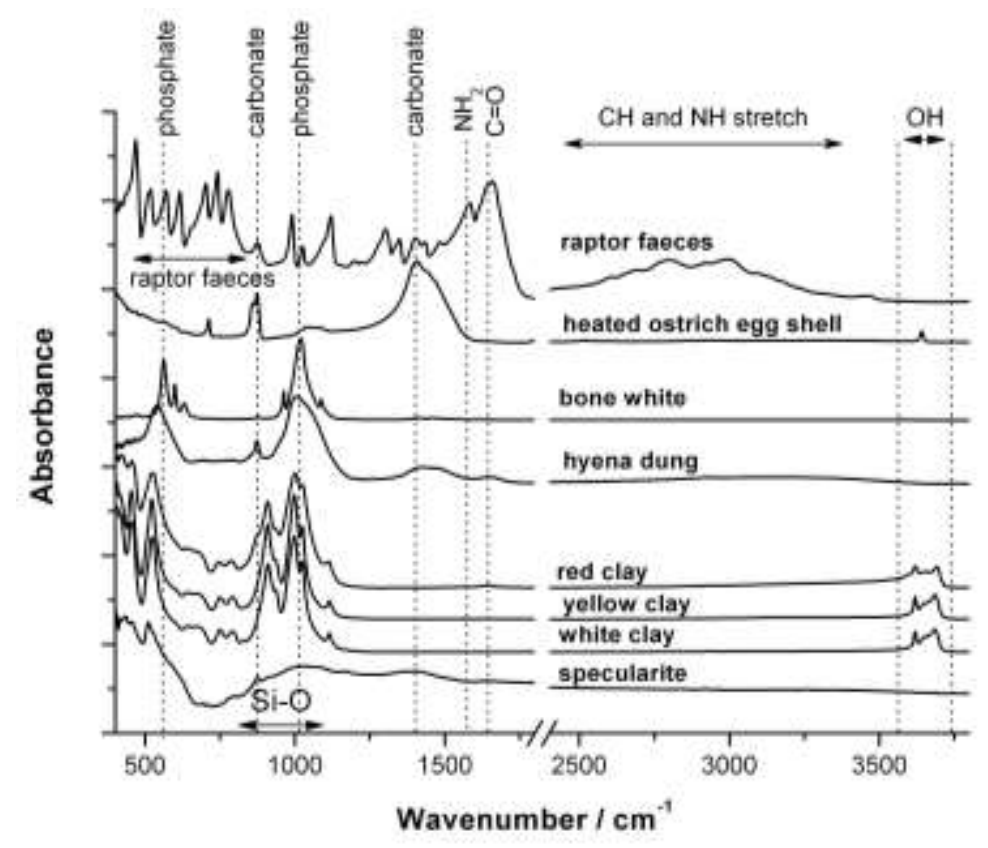

Figure 6: FTIR spectra of the pigments used in this study

Spectra recorded of the 5 paints are presented in Figure 7. Paint 1 consists of specularite, animal fat and egg. The presence of organic material is immediately clear from the strong $\mathrm{CH}$ vibrations in the spectrum, the presence of animal fat is identified through the two marker bands for fat $\left(1740,1176 \mathrm{~cm}^{-1}\right)$, the specularite by the broad band around $1000 \mathrm{~cm}^{-1}$ together with the sharp peak at $512 \mathrm{~cm}^{-1}$ and the egg by the two small amide I\&II peaks. However, if it was not known that specularite was used the peaks could be attributed to clay. Likewise the amide peaks could have originated from either blood or gall. Paint 2 contains yellow clay and egg. $\mathrm{CH}$ and amide peaks originate from the egg and $\mathrm{Si}-\mathrm{O}$ stretch vibrations together with very sharp bands originating from $\mathrm{OH}$ vibrations identify the presence of the clay (ochre). Paint 3 consists of raptor faeces, saliva, water and egg white. All the bands in the spectrum are exactly the same as for raptor faeces, water and saliva cannot be identified in an infrared spectrum and the egg white spectrum is obscured. Paint 4 is made up of egg and bone white. The amide and $\mathrm{CH}$ peaks (egg) are too faint to be easily observed in the figure, but can be identified by zooming in. The phosphate peaks are distinct. The spectrum of Paint 5 (charcoal, gall, egg, blood and saliva) was very weak and had to be multiplied to clearly observe the peaks. The amide peaks can originate from egg, blood or gall, but the presence of the broad peak in the region where the two marker peaks of gall is, implies that the greatest contribution to the spectrum is from gall. It 
also highlights the fact that in a paint mixture some peaks present in the raw material may be lost or broadened - making exact identifications difficult.

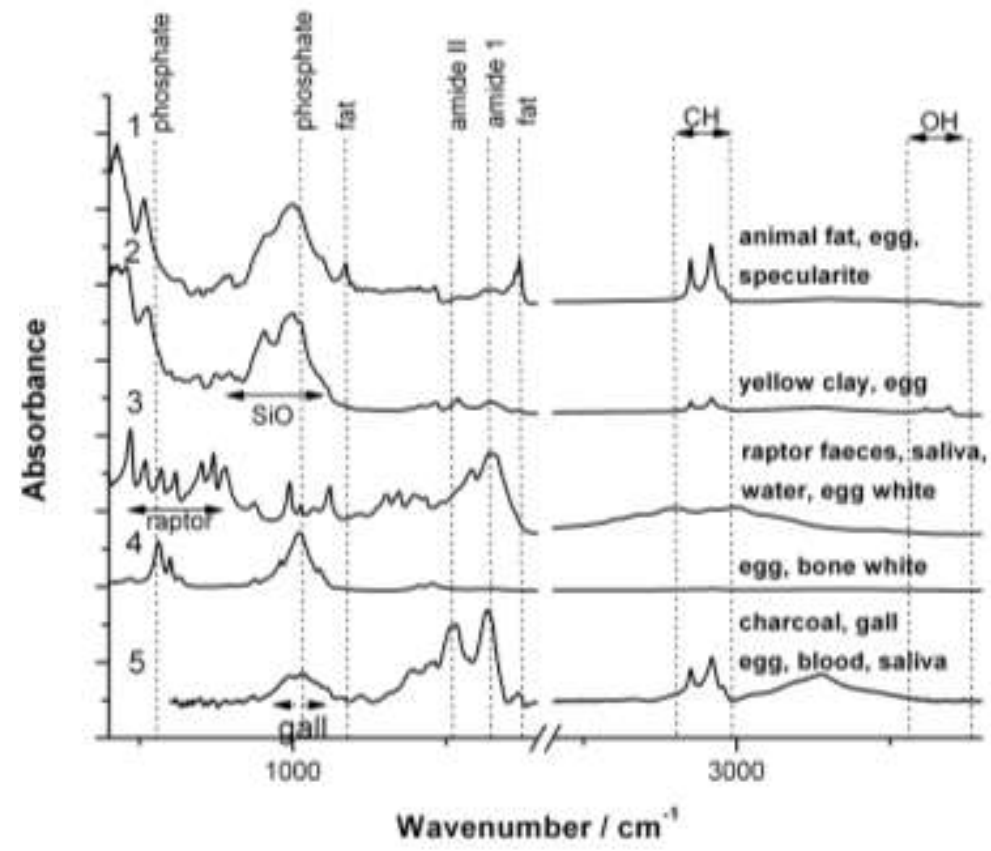

Figure 7: FTIR spectra of five replica paints

\subsection{Raman (514.6 $\mathrm{nm}$ and $785 \mathrm{~nm}$ excitation)}

In contrast to FTIR spectroscopy, where one spectrum represents the main composition of the bulk of a sample (analyses area in ATR cell $2 \mathrm{~mm}^{2}$ and most of the ingredients contributing to the IR signature), recording Raman spectra of inhomogeneous material in many instances requires more that one spectrum to reflect the composition of a sample as areas analysed are typically $1-2 \mu \mathrm{m}^{2}$. This is an important fact to take into account during on-site measurements without the ability to observe the area under examination with a video camera. In cases like these it is suggested that the objective head should be moved in small steps recording many spectra on slightly different positions. Furthermore the Raman signature of ingredients highly depends on the chemical bond polarisability and a minor component may exhibit much stronger peaks than a major one. Both the red and green laser lines are representative of those available in a mobile Raman set-up (Colomban, 2012). 


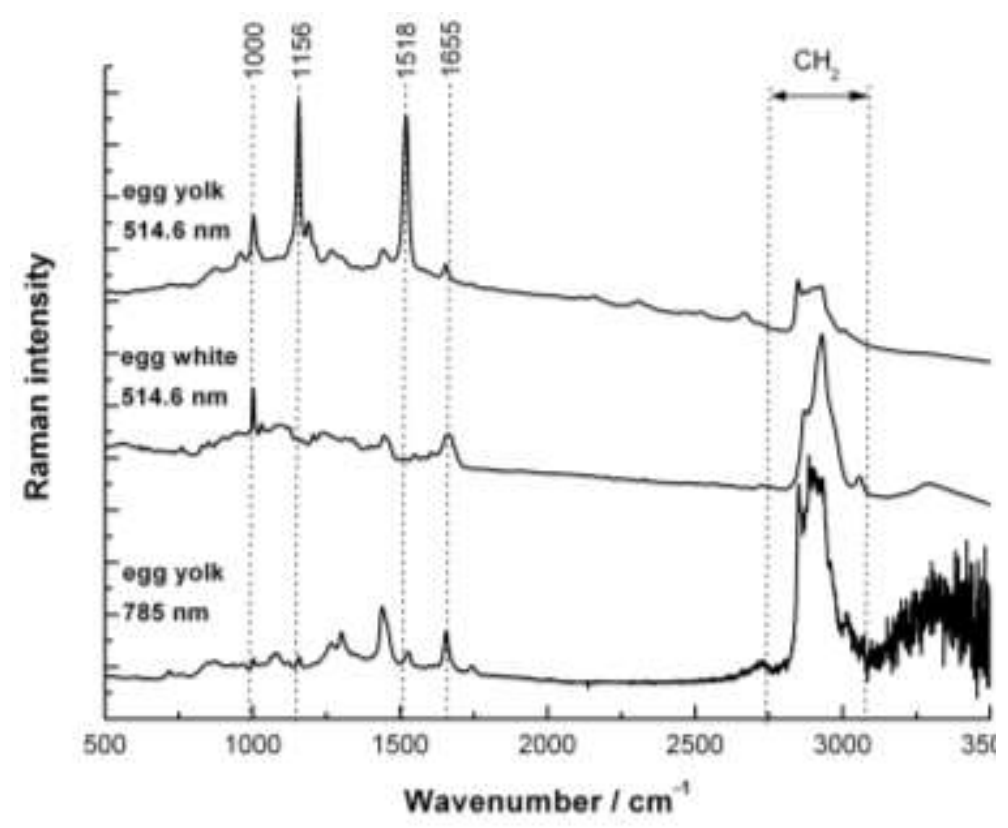

Figure 8: Raman spectra of egg yolk (514.5 and $785 \mathrm{~nm})$ and egg white recorded with $514.6 \mathrm{~nm}$ excitation.

A strong fluorescence background in most samples in general hampered recording Raman spectra with $514.6 \mathrm{~nm}$ excitation for most samples and for many samples this was also experienced for the $785 \mathrm{~nm}$ line. In Figure 8 the spectra for egg white and yolk recorded with $514.6 \mathrm{~nm}$ excitation are compared to the spectrum of egg yolk recorded with a $785 \mathrm{~nm}$ laser line. The three most prominent bands in the spectrum of the egg yolk recorded with the green line can be attributed to the carotenoid pigments lutein and zeaxanthin, which gives the yolk its characteristic yellow colour, with peaks at $1521 \mathrm{~cm}^{-1}\left(v_{1},-C=C\right.$ - stretching vibrations $), 1156 \mathrm{~cm}^{-1}$ $\left(v_{2}\right.$, -C-C- stretching) and $1005 \mathrm{~cm}^{-1}\left(\mathrm{v}_{3},-\mathrm{CH}_{3}\right.$ in-plane rocking vibrations) (Withnal et al., 2003 Maguregui, M. et. al., 2012). These peaks, previously observed in rock art paintings (Hernanz et al., 2008; Prinsloo et al., 2008; Tournié et al., 2010) are resonance enhanced with $514.6 \mathrm{~nm}$ excitation and provide ideal marker bands for egg yolk (or mixtures). However, a factor that has to be taken into account is that many lichen and bacteria are also coloured with carotenoid pigments and therefore care should be taken to ensure that the correct conclusions are drawn. The peak at $1005 \mathrm{~cm}^{-1}$ overlaps with the very characteristic ring breathing mode of the protein phenylalanine at $1003 \mathrm{~cm}^{-1}$ (Spiro and Gaber, 1977) and therefore it is also a strong peak in the spectrum of the egg white, which consists mostly of proteins including phenylalanine (see Fig. S1, where chromatographic data for egg yolk and white is given). In contrast, the spectrum recorded with the red laser line of the yolk is very 
similar to the egg white as no resonance enhancement occurs for red excitation. Green excitation is therefore optimal for detecting carotenoid pigments in rock art, but care should be taken to interpret the information correctly.
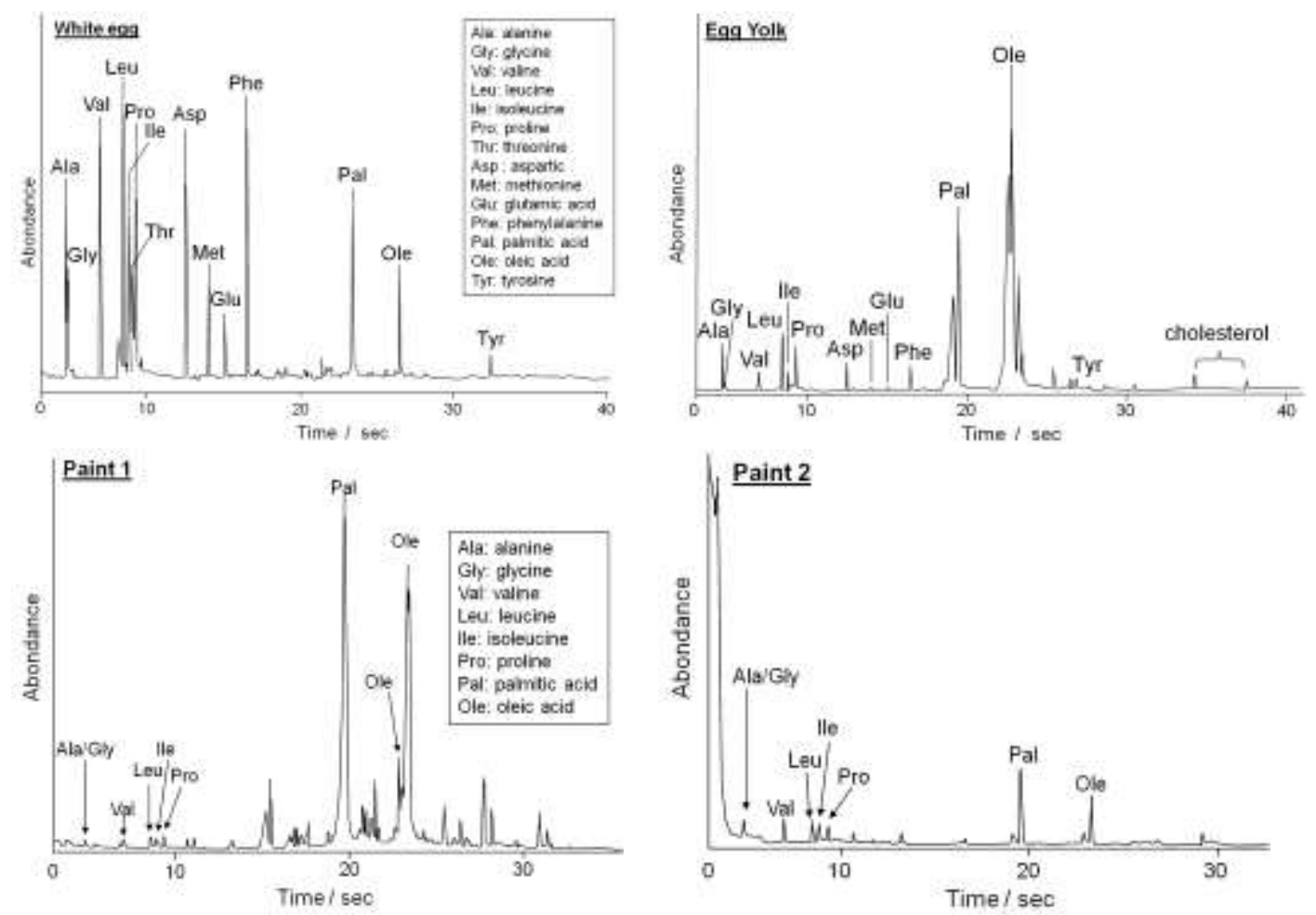

Figure S1: Chromatograms of egg white, egg yolk, paint samples 1 and 2 recorded with GC/MS HP 5890 instrument.

It was not possible to record spectra of blesbuck gall with either the 514.6 or $785 \mathrm{~nm}$ laser lines due to a too high fluorescence background (also not with a $532 \mathrm{~nm}$ laser line - not shown in the paper). Mixed into a fat mixture the fluorescence was still too high to record a spectrum with the green line. Using the red line a spectrum could be obtained with the laser set to a very low laser power, but the spectrum consisted only of bands originating from fat. It will therefore not be possible to detect the presence of gall using Raman spectroscopy. Similar to the FTIR data the heated animal fat spectrum differed from the raw fat (not shown), due to the separation of proteins and fats during heating (rendering). Marker bands for animal fat are 1738, 1653, 1438 and $1298 \mathrm{~cm}^{-1}$ (Fig. 9). The spectrum of yellow marrow bone fat, which due to its consistency is an ideal fat to paint with, also displays the typical bands of a carotenoid pigment with green excitation. It would therefore be advantageous to use red excitation to distinguish between egg and fat, where the strong bands of the carotenoid pigments are eliminated. 


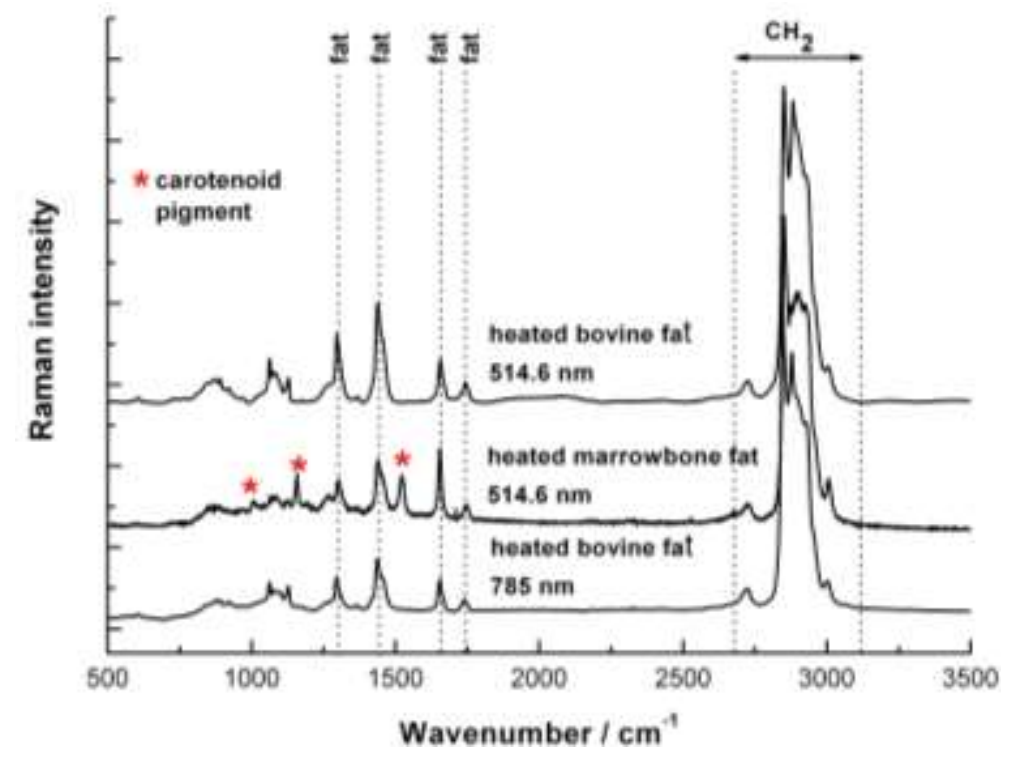

Figure 9: Raman spectra of heated fat (514.5 and $785 \mathrm{~nm}$ excitation) and heated marrowbone fat $(514.6 \mathrm{~nm})$

Raman spectra of the white pigments (hyena dung, bone white, heated ostrich egg shell, raptor faeces and white clay) are shown in Figure 10. A baseline correction was made for all the samples to eliminate a high fluorescence contribution, which in general was higher for the green line than the red. The spectrum of bone white has a very sharp peak at $961 \mathrm{~cm}^{-1}$, typical of a phosphate (Bell et al., 1997). In the hyena dung spectrum the phosphate peak is broadened and shifted to lower wavenumbers $\left(951 \mathrm{~cm}^{-1}\right)$ similar as for the FTIR results and the peak at $1084 \mathrm{~cm}^{-1}$ shows the presence of $\mathrm{CaCO}_{3}$. The most intense peak in the powdered ostrich egg shell spectrum is at $3614 \mathrm{~cm}^{-1}$, representing the $\mathrm{OH}$ stretch vibration of calcium hydroxide the main component of calcined ostrich egg shell. The two broad peaks typical of amorphous carbon $\left(\sim 1350, \sim 1600 \mathrm{~cm}^{-1}\right)$ indicate that the combustion process of the organic phase in ostrich egg shell was not complete. The peak at $1084 \mathrm{~cm}^{-1}$ belongs to $\mathrm{CaCO}_{3}$. The Raman spectrum of raptor faeces is basically the same as uric acid spectrum and the presence of the combination of peaks at 1650,1405, 1038 and $625 \mathrm{~cm}^{-1}$ are excellent marker bands for this compound. It should be noted that the fluorescence was very high - again less pronounced using the red line. Four distinct peaks in the spectrum of the white clay are $\mathrm{OH}$ vibrations that appear between $3500-3700 \mathrm{~cm}^{-1}$ and similar to FTIR measurements would indicate the presence of a clay mineral. The bands below $1000 \mathrm{~cm}^{-1}$ overlaps with many other bands such as quartz and might be difficult to assign to a specific clay and it should be noted that not all clays will have exactly the same spectrum. 


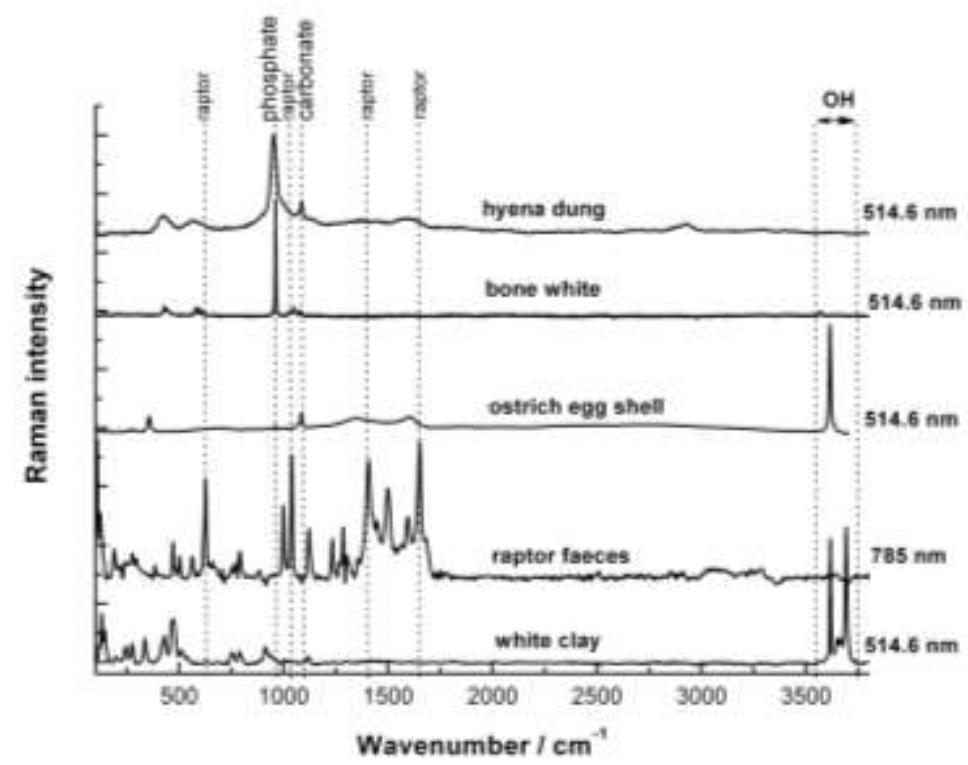

Figurre 10: Raman spectra of white pigments used in this study

In contrast to the FTIR spectrum of specularite the Raman spectrum (Fig. 11) consists of sharp peaks typical of a highly crystalline material and appear at the positions for haematite namely 225, 244, 296, 410, 500, 611 and $1317 \mathrm{~cm}^{-1}$ (Froment et al., 2008). Both green and red excitation gave good spectra, but there is a slight wavenumber shift of the peaks, due to pre-resonance conditions. It is also clear that the second order peak at $1315 \mathrm{~cm}^{-1}$ is resonantly enhanced in the spectrum recorded with the $514.6 \mathrm{~nm}$ laser line and in on-site measurements this is in many instances the strongest peak in the spectrum (Tournié et al., 2010). It was very difficult to obtain good spectra of the yellow and red clay using either one of the laser lines. Anatase was detected in all three clay samples. The spectrum recorded of the pigment the red ochre (clay) differs quite a bit from the highly crystalline spectrum The very prominent $\mathrm{O}-\mathrm{H}$ bands of kaolinite observed in the spectrum of the white clay is not present in this spectrum, probably due to the use of a very low laser power that was necessary for recording the red pigment. Similar spectra have previously been recorded of red paint on San rock art in the uKhahlamba-Drakensberg Park, where it was shown that the red ochre in the region contained both kinds of haematite (Prinsloo et al., 2008). It is also quite likely that specularite, a scarce mineral, can be added to a basic recipe of red clay that was readily available to enhance the colour properties of the paint. 


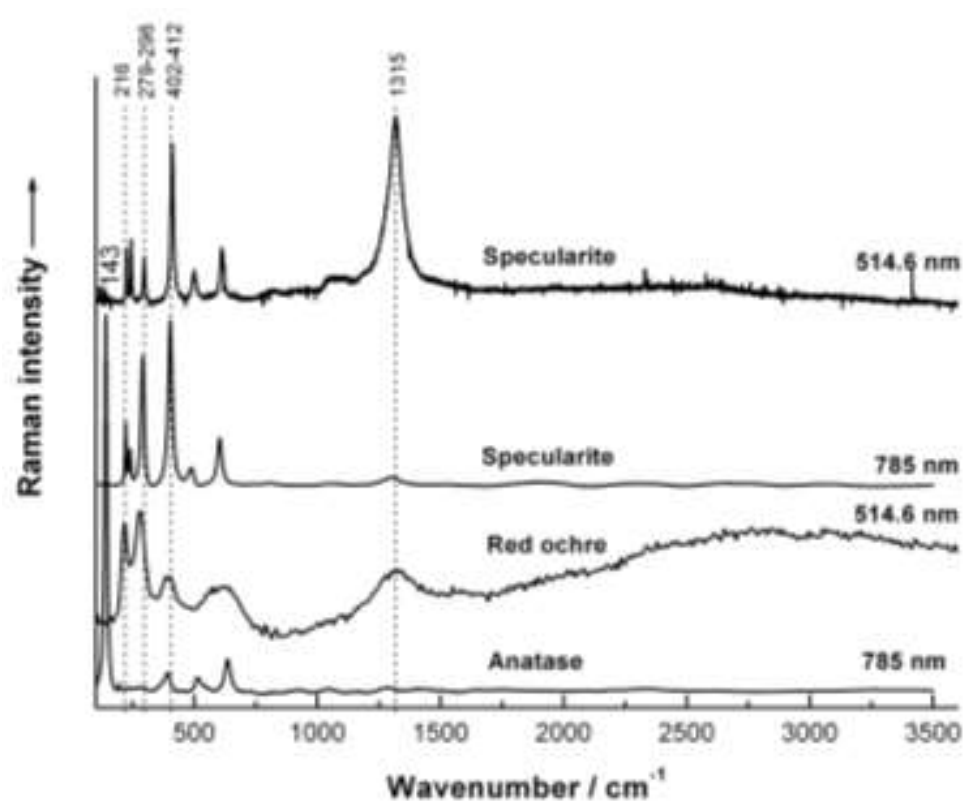

Figure 11: Raman spectra of red pigments used in this study

In Figure 12 Raman spectra $(514.6 \mathrm{~nm})$ recorded on the paint samples are shown. It was not possible to record any spectrum of the sample containing raptor faeces with either red or green excitation due to excessive fluorescence. Two spectra of paint sample 1 (animal fat, egg and specularite) are presented in the figure and in both spectra the bands originating from specularite can be identified. In the top spectrum an organic phase is detected through the $\mathrm{CH}$ vibrations and in the second spectrum a band of $\alpha$-quartz is present. It is therefore clear that many spectra have to be recorded to obtain a clear picture of the composition of the paint (in many spectra only fluorescence was observed). The spectrum of paint sample 2 (yellow ochre and egg) has peaks typical of goethite $\left(300,390 \mathrm{~cm}^{-1}\right)$ indicated with an asterisk on the figure. Very low laser powers was used to obtain the spectrum, but as the amorphous carbon peaks indicate it starting burning due to the longer exposure times used. No spectrum could be obtained from sample 3 (raptor faeces and egg white) with either of the laser lines. The phosphate peak at $961 \mathrm{~cm}^{-1}$ is quite strong in the spectrum of sample 4 (egg and bone white) and the presence of fat (or egg) is seen by the presence of $\mathrm{CH}$ vibrations and a small peak at $1440 \mathrm{~cm}^{-1}$. Sample 5 has charcoal as colouring agent and only the amorphous carbon peaks are observed. 


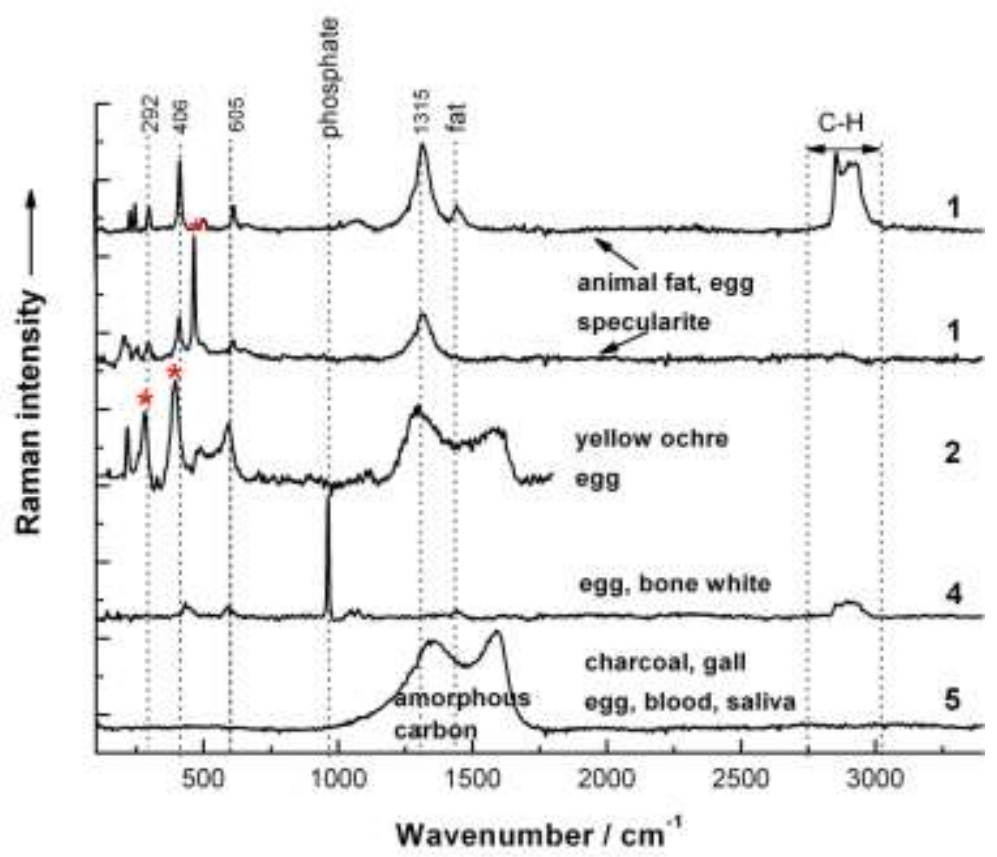

Figure 12: Raman spectra of paint samples 1, 2, 4 and 5. recorded with 514.6nm excitation

An interesting observation was made by recording Raman spectra of fresh egg yolk and a mixture of fresh egg yolk and specularite (Fig. 13). In this instance peaks from both ingredients can be clearly distinguished in the spectrum of the mixture. It might be an indication that the aging process of paint may have a great influence on the possibility to detect it using Raman spectroscopy. This is an aspect that will have to be investigated in the future.

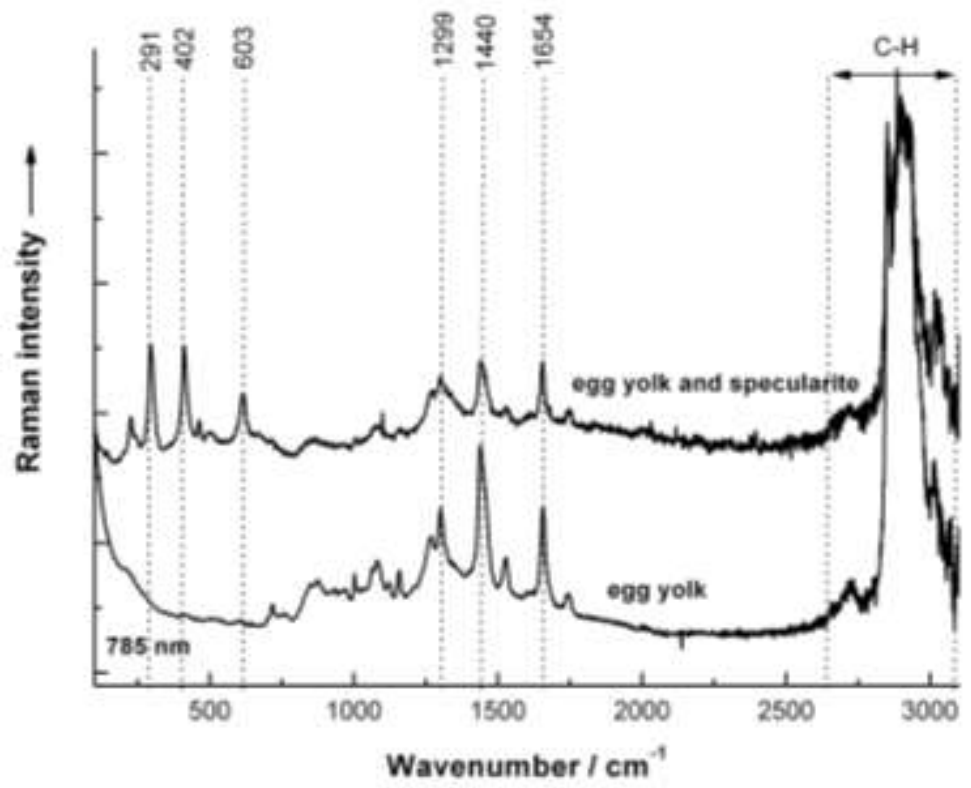

Figure 13: Comparison of Raman spectra of fresh egg yolk and egg yolk mixed with specularite 
The possibility that ingredients were added to the paint for symbolic reasons motivated the recording of a spectrum of cobra venom as it seams reasonable that it could have been added on painted arrowheads to imitate real hunting practices. In Figure 14 the FTIR and Raman (514.6 and 785nm excitation) spectra of the venom are given. Snake venom is a complex mix of hundreds, even thousands of proteins (toxic and non-toxic) and the spectra a reflection of this complexity. The two Raman spectra have bands at the same positions, but it is clear that in the spectrum recorded with the green line the $\mathrm{CH}$ vibrations are much stronger. The FTIR spectrum is dominated by protein bands without many distinguishing features. The peaks in the Raman spectra in general are sharper and the occurrence of the amide I band at $1672 \mathrm{~cm}^{-1}$ is indicative of protein antiparallel- $\beta$ structure. This is typical of Cobramine B, a basic protein from cobra venom, and a good marker band as not one of the other ingredients have a band in this region (Yu et al., 1973).

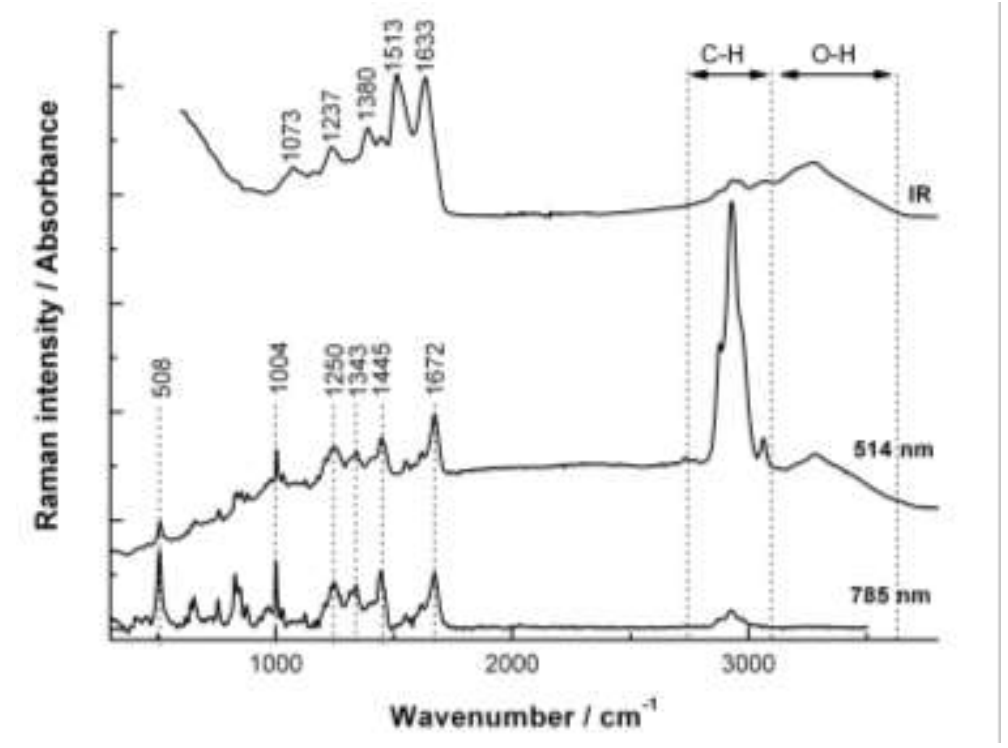

Figure 14: The infrared and Raman spectra of cobra venom.

\subsection{GCMS}

In order to assign the bands in the spectra of white and yolk GCMS spectra were recorded and different components identified. The paint samples were mixed to prepare viable paints and no exact measurements of added ingredients were undertaken. Therefore the paints were also controlled with GCMS to ascertain if expected ingredients are effectively present in the paints. Examples can be seen in Figure S1, where it is clear that the quantity of egg in Paint 1 is more than in Paint 2. 


\section{Conclusion}

Table 2 summarizes the IR and Raman bands that can potentially be used to identify ingredients in rock art paint, bands that specifically can be used as markers are highlighted. It is clear that it is possible to record FTIR spectra of all the ingredients, except charcoal. However, in many of the organic samples the protein bands are the strongest feature and if there are no other characteristic bands in the spectra it will be difficult to distinguish between proteins. The inherent broadness of FTIR bands also causes many bands to overlap, which can make is difficult to identify specific ingredients in mixtures. Furthermore, sampling is mandatory if the FTIR spectra are recorded in transmission or absorbance mode, while on-site spectroscopy is possible for Raman analysis. Recently portable FTIR instruments have become available and minerals have been successfully identified through their FTIR reflectance spectra (Ostrooumov M. 2009). A smooth surface is however necessary to obtain good spectra and for rock art analysis where organic material might also be present a transmission-reflectance spectrum will be obtained, which is quite difficult to interpret.

Although in many instances problems experienced with a high fluorescence background was less for $785 \mathrm{~nm}$ excitation, Raman spectroscopy using green excitation still proves to be the more versatile and most organic and inorganic ingredients could be identified. Experimentation to find ways and means to eliminate fluorescence has to be undertaken.

The studied replica paints are fresh or a few years old and we have illustrated that the freshly prepared mixtures are easier to analyse than the ten year old paints. The next step will be to broaden the study to paints exposed to accelerated degradations conditions that mimic what happens to the rock art (UV, etc.). A further aspect that has to be taken into consideration is that the binders and carrying agents studied, mainly consists of proteins and lipids which are nutrients for all living organisms. In an open cave or shelter it is highly likely that the organic part of the paint may disappear as food source for insects, etc. Encapsulation of organic phases by inorganic crusts, such as oxalates, has made it possible to detect organic phases in these instances (Spades and Russ 2005, Díez-Herrero 2009). 
Table 2: Summary of FTIR and Raman bands, marker bands are highlighted

IR MID ATR Bruker instrument (University of Pretoria) - Figs. 1 to 3

\begin{tabular}{|c|c|c|c|}
\hline & Ingredient & Phases & Intense peaks / $\mathrm{cm}^{-1}$ \\
\hline \multirow{6}{*}{ Minerals } & Ochre & $\begin{array}{l}\text { v Si-O-Si (quartz) } \\
\text { vOH, Clay minerals }\end{array}$ & $\begin{array}{l}1030(\mathrm{~b}) \\
3620,3628\end{array}$ \\
\hline & Specularite & Haematite $\mathrm{Fe}_{2} \mathrm{O}_{3}$ & 1000 (br) \\
\hline & Ostrich egg shell & $\mathrm{CaCO}_{3}$ & 872,1410 \\
\hline & Bone white & Phosphate & 1090, 1020(vs), 962, 562(vs) \\
\hline & Hyena dung & Phosphate & 1001,537 \\
\hline & Charcoal & Not observed & - \\
\hline \multirow{6}{*}{ Organics } & Egg white & Protein, Amide I \& II & 1636,1543 \\
\hline & Egg yolk & $\begin{array}{l}\text { Protein, Amide I \& II } \\
v \square \mathrm{C}=\mathrm{O} \text {, fatty acid } \\
\mathrm{v} \square \mathrm{C}-\mathrm{H} \text {, fatty acid }\end{array}$ & $\begin{array}{l}1636,1543 \\
1744 \\
2923\end{array}$ \\
\hline & Heated fat & $\begin{array}{l}\mathrm{v} \square \mathrm{C}=\mathrm{O} \text {, fatty acid, } \delta \mathrm{CH}_{2} \& \mathrm{CH}_{3} \\
\mathrm{v} \square \mathrm{C}-\mathrm{O} \text {, fatty acid, } \mathrm{CH}_{2} \\
\mathrm{v} \square \mathrm{C}-\mathrm{H} \text {, fatty acid }\end{array}$ & $\begin{array}{l}1740,1466 \\
1175,722 \\
2923\end{array}$ \\
\hline & Raptor faeces & Uric acid, $\mathrm{C}=\mathrm{O}, \delta \mathrm{NH}_{2}$ & $\begin{array}{l}1658,1582 \\
777,742,702\end{array}$ \\
\hline & Gall & Protein and unknowns & $1635,1546,1048,1073$ \\
\hline & Cobra venom & Amide I \& II & $1635,1534,1380,1237,1073$ \\
\hline \multicolumn{4}{|c|}{ Raman $785 \mathrm{~nm}$, Senterra Bruker instrument (LADIR) - Figs 4 to 10} \\
\hline & Ingredients & Phases & Intense peaks / $\mathrm{cm}^{-1}$ \\
\hline \multirow{5}{*}{ Minerals } & Ochre & Haematite $\mathrm{Fe}_{2} \mathrm{O}_{3}$ & 295,410 \\
\hline & Specularite & Haematite $\mathrm{Fe}_{2} \mathrm{O}_{3}$ & 290,405 \\
\hline & Ostrich egg shell & $\mathrm{CaCO}_{3}$ & 1084 \\
\hline & Bone white & Phosphate & 961 \\
\hline & Charcoal & Amorphous carbon & $\sim 1300, \sim 1600$ (br) \\
\hline \multirow{6}{*}{ Organics } & Egg White (fresh) & $\begin{array}{l}\text { Protein, Amide I, C-H bending } \\
\text { Fatty acid } v \square \mathrm{C}=\mathrm{O}, v \square \mathrm{C}-\mathrm{H}\end{array}$ & $\begin{array}{l}1654,1440 \\
1744,2923\end{array}$ \\
\hline & Egg Yolk (fresh) & $\begin{array}{l}\text { Protein, Amide I } \\
v \square \mathrm{C}-\mathrm{H}, \text { fatty acid }\end{array}$ & $\begin{array}{l}1654,1440, \\
2890\end{array}$ \\
\hline & Fat (heated) & Fatty acid & 3020 \\
\hline & Raptor faeces & Uric acid & $1650,1405,1038,625$, \\
\hline & Gall & - & - \\
\hline & Cobra venom & $\begin{array}{l}\text { Protein antiparallel } \beta \text {-structure } \\
\text { C-H }\end{array}$ & $\begin{array}{l}1672 \\
2800-2900(\mathrm{~s})\end{array}$ \\
\hline
\end{tabular}

Raman 514nm, T64000 Horiba Jobin Yvon instrument (University of Pretoria) - Figs 4-10

\begin{tabular}{|c|c|c|c|}
\hline & Ingredients & Phases & Intense peaks $/ \mathrm{cm}^{-1}$ \\
\hline \multirow{5}{*}{ Minerals } & Ochre & Haematite & $1312,3618,3650,3665,3683$ \\
\hline & Specularite & Crystalline haematite $\mathrm{Fe}_{2} \mathrm{O}_{3}$ & $225,244,296,410,500,611$ \\
\hline & Ostrich egg shell & Calcite & 1083 \\
\hline & Bone white & Phosphate & 961 \\
\hline & Charcoal & Carbon & 1358,1587 (br) \\
\hline \multirow{6}{*}{ Organics } & Egg white & $\begin{array}{l}\text { Protein, Amide I, C-H bending } \\
\text { Phenylalnine } \\
v \square \mathrm{C}-\mathrm{H} \text {, fatty acid }\end{array}$ & $\begin{array}{l}1664,1447 \\
1003 \\
2929\end{array}$ \\
\hline & Egg yolk & Carotenoid & $1521,1156,1005$ \\
\hline & Heated fat (marrow) & $\begin{array}{l}\text { Farry acid } \\
\text { Carotenoid pigment }\end{array}$ & $1738,1653,1438,1298$ \\
\hline & Raptor faeces & Uric acid & $1650,1405,1038,625$ \\
\hline & Gall & - & - \\
\hline & Cobra venom & $\begin{array}{l}\text { Protein, antiparallel } \beta \text {-structure } \\
\text { C-H }\end{array}$ & $\begin{array}{l}1672 \\
2800-2900(\mathrm{vs})\end{array}$ \\
\hline
\end{tabular}

Note that between different instruments a small variation in wavenumber positions might occur 


\section{Acknowledgment}

The authors wish to thank Dr. Sophie Rochut for performing the Mass Spectroscopy analysis. We gratefully acknowledge the financial support of NRF/CNRS, LADIR and the University of Pretoria

\section{References}

Avery, D. M., 2007. Pleistocene micromammals from Wonderwerk Cave, South Africa: practical issues. J. Archae. Sc. 34, 613-625.

Baeten, V., Hourant, P., Morales, M. T. and Aparicio R., 1998. Oil and fat classification by FT-Raman Spectroscopy. J. Agric. Food Chem. 46, 2638-2646.

Bassett, S. T., 2001. Rock paintings of South Africa, David Philip ed, Cape Town.

Bell, I. M., Clark, R. J. H. and Gibbs, P.J., 1997. Raman spectroscopic library of natural and synthetic pigments (pre- 1850 AD). Spectrochimica Acta part A. 53, 2159-2179.

Bezuidenhout, R., Van der Merwe, L., and Prinsloo, L. C., 2010. A comparison of the change in thermal behaviour and composition of Ostrich egg and Achatina shells upon thermal treatment. European Symposium on Thermal Analysis and Calorimetry, Rotterdam, Netherlands.

Bonneau, A., Pearce, D.G., Pollard, A.M., 2012. A multi-technique characterization and provenance study of the pigments used in San rock art, South Africa J. Archae. Sc. 39, 287-294.

Colomban, Ph. 2012 The on-site/remote Raman analysis with portable instruments - A review of drawbacks and success in Cultural Heritage studies and other associated fields, J. Raman Spectrosc. 43 (11).1529-1535.

Derieux A., Rochut S., Papillon M.-C., Pepe C., 2001. Identification des colles protéiques présentes dans les œuvres d'art par couplage $\mathrm{CG} / \mathrm{MS}$ à trappe d'ions, C. R. Acad. Sci. 4, 295-300.

Díez-Herrero A, Gutiérrez-Pérez I, Lario J, Cañaveras J. C., Benavente D., Sergio Sánchez-Moral S. and Alonso-Azcárate J. 2009 Analysis of potential direct insolation as a degradation factor of cave paintings in Villar del Humo, Cuenca, Central Spain, Geoarchaeology 24, 450-465.

Edwards H. G. M., Drummond L. and Russ J. 1999 Fourier transform Raman spectroscopic study of prehistoric rock paintings from the Big Bend region, Texas J. Raman Spectrosc. 30, 421-428. 
Edwards, H. G. M., Drummond, L., Russ, J., 1998. Fourier-transform Raman spectroscopic study of pigments in native American Indian rock art: Seminole Canyon. J. Spectrochim. Acta Part A. 54, 1849-1856.

Edwards, H. G. M., Newton, E. M., Russ, J., 2000. Raman spectroscopic analysis of pigments and substrata in prehistoric rock art. J. Mol. Struct. 245, 550-551.

Froment, F., Tournié, A., Colomban, Ph., 2008. Raman identification of natural red to yello pigments: ochre and iron-containing ores. J. Raman Spectrosc. 39, $560-568$

Gallagher W. FTIR analysis of protein structure.

http://www.chem.uwec.edu/Chem455_S05/Pages/Manuals/FTIR_of_proteins.pdf

Gialanella, S; Belli, R; Dalmeri, G ; Lonardelli, I; Mattarelli, M; Montagna, M; Toniutti, L 2011 Artificial or natural origin of hematite-based red pigments in archaeological contexts: the case of Riparo Dalmeri (Trento, Italy) Archaeometry $53,950-962$

Goodall, R.A., David, B., Kershaw, P., Fredericks, P.M, 2009. Prehistoric hand stencils at Fern Cave, North Queensland (Australia): environmental and chronological implications of Raman spectroscopy and FT-IR imaging results. J. Archaeo. Sc. 36, 2617-2624.

Henshilwood, C. S., d'Errico, F., van Niekerk, K.L., Coquinot, Y., Jacobs, Z., Lauritzen, S., Menu, M. and Garcia-Morena, R., 2011. A 100 000-year-old ochreprocessing workshop at Blombos Cave, South Africa. Science. 334, 219-222.

Hernanz A., Mas M., Gavilán B. and Hernández B. 2006 Raman microscopy and IR spectroscopy of prehistoric paintings from Los Murciélagos cave (Zuheros, Córdoba, Spain) J. Raman Spectroscopy 37, 492-497.

Hernanz. A., Gavira-Vallejo, J. M., Ruiz-Lopez, J. F., Edwards, H. G. M., 2008. A comprehensive micro-Raman spectroscopic study of prehistoric rock paintings from the Sierra de las Cuerdas, Cuenca, Spain. J. Raman Spectrosc. 39, 972- 984.

Hernanz, A., Ruiz-Lopez, J. F. Gavira-Vallejo, J. M. Martin, S. Gavrilenko, E., 2010. Raman microscopy of prehistoric rock paintings from the Hoz de Vicente, Minglanilla, Cuenca, Spain. J. Raman Spectrosc. 41, 1394-1399.

Hernanz, A., Gavira-Vallejo, J.M., Ruiz-López, J.F., Martin, S., Maroto-Valiente, A., De Balbín-Behrmann, R., Menéndez, M., 2012. Spectroscopy of Palaeolithic rock paintings from the Tito Bustillo and El Buxu Caves, Asturias, Spain. J. Raman Spectrosc. 43, 1644-1650.

Johnson, T., 1957. An experiment with cave-painting media, S. Afr. Archaeol. Bull. 12, 98-101.

Lahlil, S., Lebon, M., Beck, L., Rousselière, H., Vignaud, C., Reiche, I., Menu, M., Paillet, P. and Plassard F., 2012. The first in situ micro-Raman spectroscopic 
analysis of prehistoric cave art of Rouffignac St-Cernin, France, J. Raman Spectrosc. 43, 1637-1643.

Lewis-Williams J. D., 1985. The San artistic achievement. Afr Arts 18, 5459.

Lewis-Williams, J. D., and Dowson, T. A., 1990. Through the Veil: San Rock Paintings and the Rock Face, South. Africa. Archaeol. Bull. 45, 5-16.

Lofrumento, C., Ricci, M., Bachechi, L., De Feo, D., Castellucci, E.M., 2012. The first spectroscopic analysis of Ethiopian prehistoric rock painting. J. Raman Spectrosc. 43, 809-816.

Madejova J. 2003 Vibrational Spectroscopy 31 [1] (2003) 1-10

Maguregui, M., Knuutinen, U., Trebolazabala, J., Morillas, H., Castro, K., Martinez-Arkarazo, I., Madariaga, J.M. 2012, Use of in situ and confocal Raman spectroscopy to study the nature and distribution of carotenoids in brown patinas from a deteriorated wall painting in Marcus Lucretius House (Pompeii), Anal. Bioanal. Chem. 402 (4), 1529-1539

Marinach C., Papillon M.-C., Pepe C., 2004. Identification of binding media in works of art by gas chromatography-mass spectrometry, J. Cult. Herit. 5, 231-240.

Olivares, M., Castro, K., Corchón, M.S., Gárate, D., Murelaga, X., Sarmiento A., Etxebarria N. 2012. Non-invasive portable instrumentation to study Palaeolithic rock paintings: the case of La Peña Cave in San Roman de Candamo (Asturias, Spain). J. Archaeo. Sc. On line, 1-7.

Ospitali, F., Smith, D. C., Lorblanchet, M., 2006. Preliminary investigations by Raman microscopy of prehistoric pigments in the wall-painted cave at Roucadour, Quercy, France. J. Raman Spectrosc. 37, 1063-1071.

Ostrooumov M. 2009 Infrared reflection spectrometry analysis as a nondestructive method of characterizing minerals and stone materials in geoarchaeological and archaeometric applications. Geoarchaeology, 24 619-637.

Prinsloo, L. C., Barnard, W., Meiklejohn, I., Hall, K., 2008. The first Raman spectroscopic study of San rock art in the Ukhahlamba Drakensberg Park, South Africa. J. Raman Spectrosc. 39, 646-654.

Ravindran, T. R., Arora, A. K., Singh, M. and Ota, S. B., 2013 On- and off-site Raman study of rock-shelter paintings at world-heritage site of Bhimbetka, J. Raman Spectrosc. 44, 108-113.

Ronat L, CNRS-Image, Soptlight on San Paintings,2010 (3é mn film) http://videotheque.cnrs.fr/index.php?urlaction=doc\&id_doc $=2223$

(Accessed November 2012) 
Rifkin, R. F. 2012 Processing ochre in the Middle Stone Age: Testing the inference of prehistoric behaviours from actualistically derived experimental data. J. Anthropol. Archaeol. 31 (2), 174-195

Rudner, I., 1983. Paints of the Khoisan rock artists S. Africa. Archaeol. Soc. Goodwin Ser. 4, 14-20.

Smith, D. C., Bouchard, M., Lorblanchet, M., 1999. An initial Raman microscopic investigation of prehistoric rock art in caves of the Quercy District, S. W. France. J. Raman Spectrosc. 30, 347-354.

Spades S. and Russ J. 2005 GC-MS analysis of lipids in prehistoric rock paints and associated oxalate coatings from the Lower Pecos region, Texas, Archaeom. $47,115-126$

Spiro, T. G. and Gaber, B. P., 1977. Laser Raman scattering as a probe of protein structure. Ann. Rev. Biochem. 46, 553-572.

Thackeray, A. I., Thackeray, J. F. and Beaumont, P. B. 1983. Excavations at the Blinkklpkop specularite mine near Postmasburg, Northern Cape, S. Afr. Archaeol. Bull. 38, 17-25.

Tournié, A., Prinsloo, L.C., Paris, C., Colomban, Ph., Smith, B., 2010. The first in situ Raman spectroscopic study of San rock art in South Africa: procedures and preliminary results. J. Raman Spectrosc. 41, 1394-1399.

Vandebabeele P, Wehling B., Moens L., Edwards H., De Reu M. and Van Hooydonk G. 2000, Analysis with micro-Raman spectroscopy of natural organic binding media and varnishes in art. Analytica Chimica Acta 407, 261-274.

Wadley L. 2005 Putting ochre to the test: replication studies of adhesives that may have been used for hafting tools in the Middle Stone Age, J. Human Evolution 49 (5) 587-601.

Wadley L, Williamson B. and Lombard M. 2004. Ochre in hafting in Middle Stone Age southern Africa: a practical role, Antiquity, 78 (301), 661-675.

Wilson E. V. Junaird Bushiri M. and Vaidyan V. 2010, Analyticla caraterization and FTIR studies od urinary calcili. Journal of Optoelectronics and Biomedical Materials 22 (2) 85-90.

Withnall, R., Chowdhry, B. Z., Silvger, J., Edwards, H. G. M. and de Oliveira, L. F. C. 2003. Spectrochimica Acta Part A. 59, 2207-2212.

Yu N., Jo B. H. and O’Shea D.C. 1973. Laser Raman scattering of Cobramine B, a basic protein from cobra venom, Archives of Biochemistry and Biophysics 156, 71-76. 
Zoppi, A., Signorini, G. F., Lucarelli, F., Bachechi, L., 2002. Characterisation of painting materials from Eritrea rock art sites with non-destructive spectroscopic techniques. J. Cult. Heritage, 3, 299-308. 